Çukurova Üniversitesi Mühendislik Mimarlık Fakültesi Dergisi, 30(2), 151-156 ss., Aralık 2015

Çukurova University Journal of the Faculty of Engineering and Architecture, 30(2), pp. 151-156, December 2015

\title{
Selection of Tool Path and Parameter in Computer Aided Production of Belt Pattern Mold
}

\author{
Tamer BAŞKAL ${ }^{* 1}$ \\ ${ }^{1}$ Kirlkkale University, Vocation of Higher Education, Machine Section, Kirlkkale
}

Geliş tarihi: 07.10.2015

Kabul tarihi:27.10.2015

\begin{abstract}
In the present study, the 3-dimensional artistic relief designs on the leather belt used to create $\mathrm{CNC}$ tool path and the parameters were investigated in the production of hot pressing molds. The 3-dimensional relief patterns obtained with the help of belt pressure molds consist of marks pressed along the belt with the hot press. These intricate patterns create the varieties in the world of wear by forming various artistic shapes on the belt. Patterns on the belt are obtained by CNC machine productions of the brass bars processed through CAD-CAM programs. In the present study, tool path and parameter values have been shown chosen by the CAM program used in the production of a relief pattern mold.
\end{abstract}

Keywords: CAD/CAM, Relief, Leather belt, CNC router, Toolpath, Pantograph cutter, Artistic CAM

\section{Bilgisayar Destekli Kemer Desen Kalıp Üretiminde Takım Yolu ve Parametre Seçimi}

\section{Özet}

$\mathrm{Bu}$ çalışmada, deri kemer üzerinde bulunan 3 boyutlu sanatsal rölyef desenlerin oluşturulmasında kullanılan sıcak baskı kalıplarının üretiminde CNC takım yolu ve parametreleri araştırılmıştır. Kemer üzerinde baskı kalıplarıyla elde edilen 3 boyutlu rölyef desenler sıcak baskı ile kemer boyunca basılan izlerden oluşmaktadır. Bu çıkıntı ve girintiler, kemerde çeşitli sanatsal görüntüler oluşturarak giyim dünyasında çeşitliliği oluşturmaktadır. Kemer üzerindeki desenler, kemer boyutundaki pirinç lama malzemeler üzerine CAD-CAM programları sayesinde işlenen CNC tezgahı üretimler ile elde edilmektedir. Bu çalışmada, bir rölyef desen kalıbının üretiminde kullanılan CAM programıyla seçilen takım yolu ve parametre değerleri gösterilmiştir.

Anahtar Kelimeler: CAD/CAM, Rölyef, Deri kemer, CNC router, Takım yolu, Pantoğraf kesici, ArtCAM

\footnotetext{
* Yazışmaların yapılacağı yazar: Tamer BAŞKAL, Kırıkkale University, Vocation of Higher Education, Machine Section, Kırıkkale, tbaskal@yahoo.com
} 


\section{INTRODUCTION}

Relief patterns on a leather belt consist of geometric or random shapes in various depths. The image of these patterns on belt is directly reflected to both belt production methods and sales quantities. Leather, the basic material which is used in the production of belt, when it has not the same tissue along the belt, the visual correction of this structural disorder entails using mold.

Moreover, producing dozens of various kinds of belts with the same material and color makes the producers more powerful during the sales phase. It may be possible to obtain hundreds of various belts with the difference of color, leather material and press pattern. For these reasons, a belt production company is forced to use pressure pattern molds.

The patterns on the belt were obtained by roll molds up to 15-20 years ago. The pattern marks were created by pressing various models on a circular mold turning on the belt. The patterns obtained this way meant all the same along the belt. However, hot relief pattern mold creates more aesthetic appearance on the belt structure.

Relief pattern modeling requested to be obtained along the belt consist of brass bar material plated with chrome-nickel, 15-20 mm thick and 1300$1350 \mathrm{~mm}$ length. The brass bar material is produced by tool path of CAM artistic program in CNC machines. Selection of tool path and tool parameters reveals important results in mold production. Because, the relief pattern heights approximately between 1,5 and 3,5 $\mathrm{mm}$ depths are obtained only by the ideal tool parameters. Examples of belt and mold (Figure 1-2).

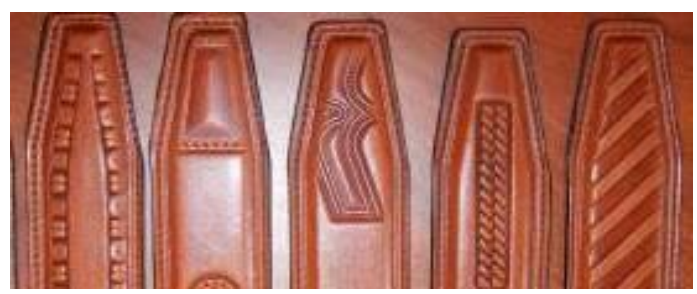

Figure 1. Examples of belt

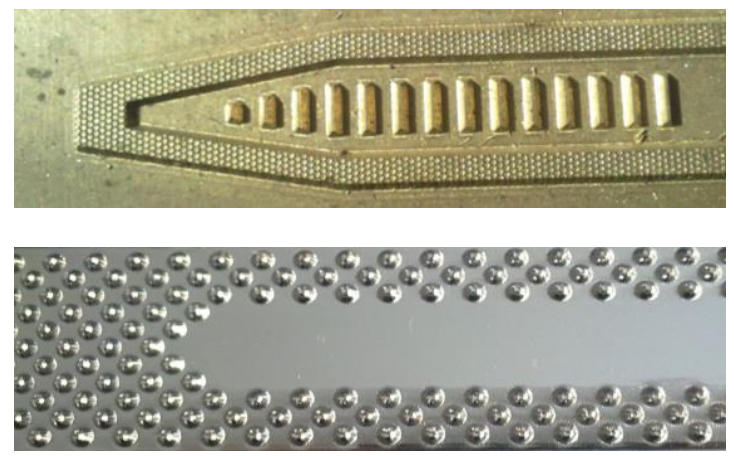

Figure 2. Examples of mold

\section{PRODUCTION OF BELT PATTERN MOLD}

Production of belt pattern molds is enabled by means of computer aided design (CAD) and computer aided manufacturing (CAM) on the $\mathrm{CNC}$ vertical process centered machines. The main lines for the production phases of these molds are as follows:

- Creating of main drawing vectors for belt pattern models by CAD program $[5,6]$ (Figure 3).

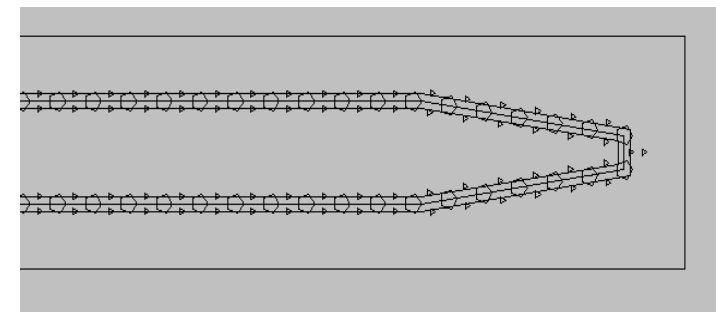

Figure 3. Two-dimensional drawing

- Giving the indent and bulge thicknesses to pattern models drawing vectors of which are created in artistic production program (CAM) [7,10] (Figure 4).

- Creating tool paths by selecting tool path and parameters in artistic production program (CAM) (Figure 5). 


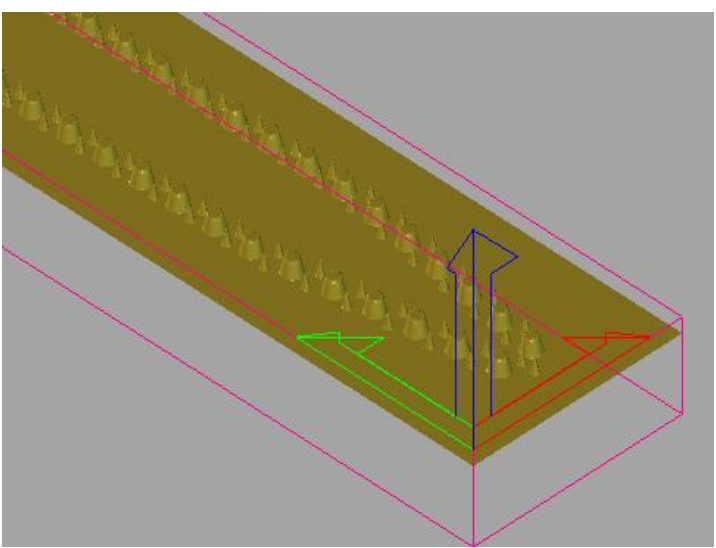

Figure 4. Three-dimensional modeling

- Creating tool paths by selecting tool path and parameters in artistic production program (CAM) (Figure 5).

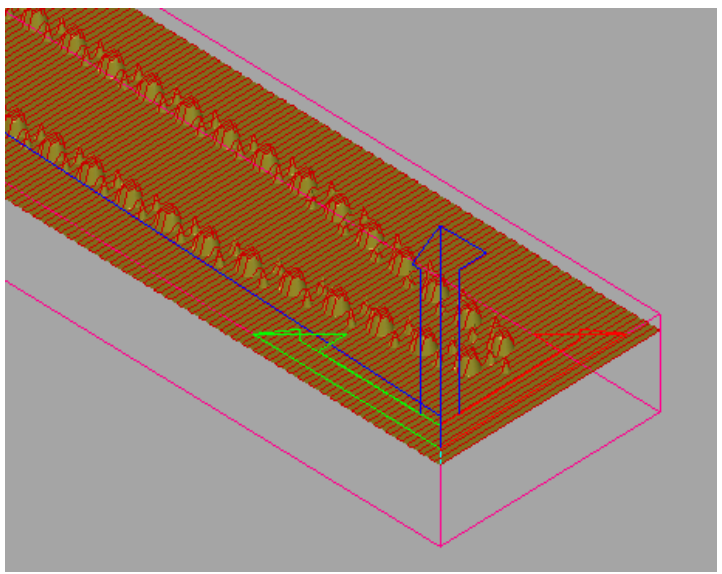

Figure 5. Creating tool path

- Processing of tool paths onFigure brass bar material with average thickness of $20 \mathrm{~mm}, 40$ $\mathrm{mm}$ width and $1350 \mathrm{~mm}$ length by means of CNC pantograph machine (Figure 6-7).

- Clearing the processing marks on the raw mold obtained after process with various methods.

- Plating the pattern mold with chrome-nickel (nickel-plating process).

In the present study, selections of tool parameters in the mold production phase will be highlighted.

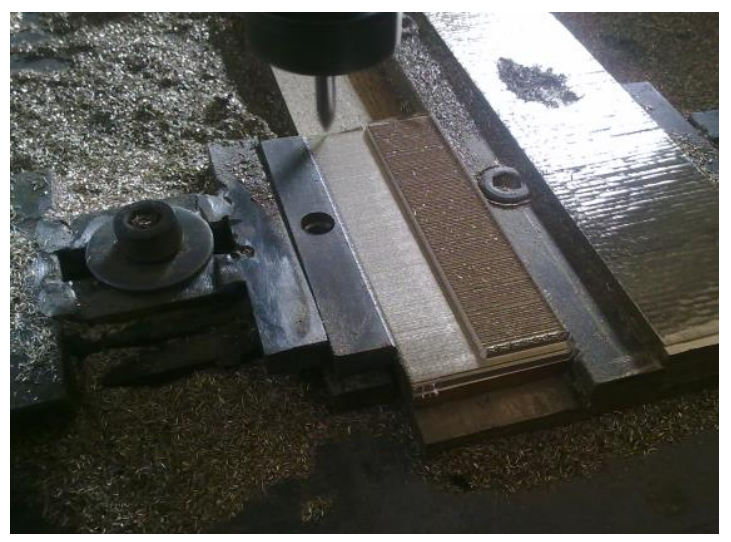

Figure 6. Mold with $\mathrm{CNC}$ pantograph machine

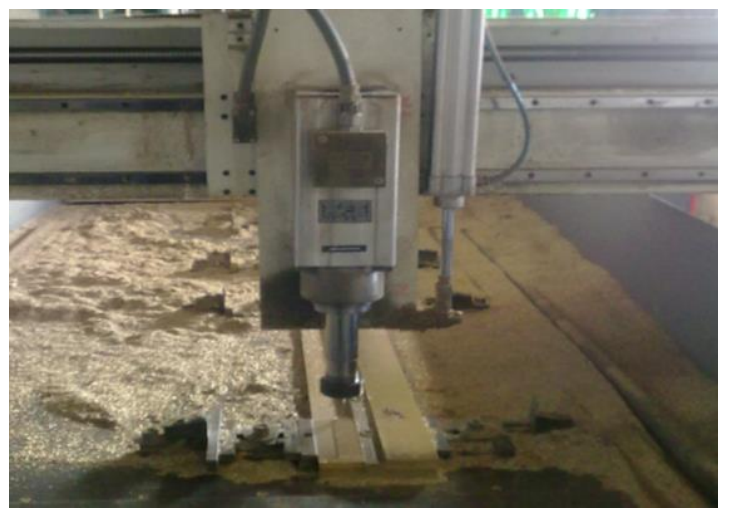

Figure 7. CNC pantograph machine

\subsection{Selection of Tool Path and Tool Parameters}

For the production of designed belt pattern mold, brass bar material (CuZn32Mn) in sizes of $20 * 40 * 1350 \mathrm{~mm}$ has been chosen as the stock part. The following phases have been listed for processing embossed design with $2,5 \mathrm{~mm}$ height on this material:

The diamond-carbide knife is sharpened as threeangle and so its cutting edge as $32^{\circ}$ on tool sharpener machine. Being the tip conic angle $32^{\circ}$ in tool sharpening, it has been determined that no dimension loss occurs in order to create $2,5 \mathrm{~mm}$ depth pattern height in relief edges. Tool cutter edge breakages in lower angles and relief shape 
losses in higher ones are experienced. For obtaining three cutter edges in sharpening the knife, it is needed to revolve it in its own axis and conic tip angle of the knife should be sharpened by revolving the $\mathrm{Z}$ axis approximately $8^{\circ}$. It has been aimed to prevent the increase in trimming quantity, tip breakages and tool abrasion in sharpening the cutter tool. In investigations, it has been determined that the three-edged cutter knife is more enduring than the two-edged cutter knife (Figure 8).

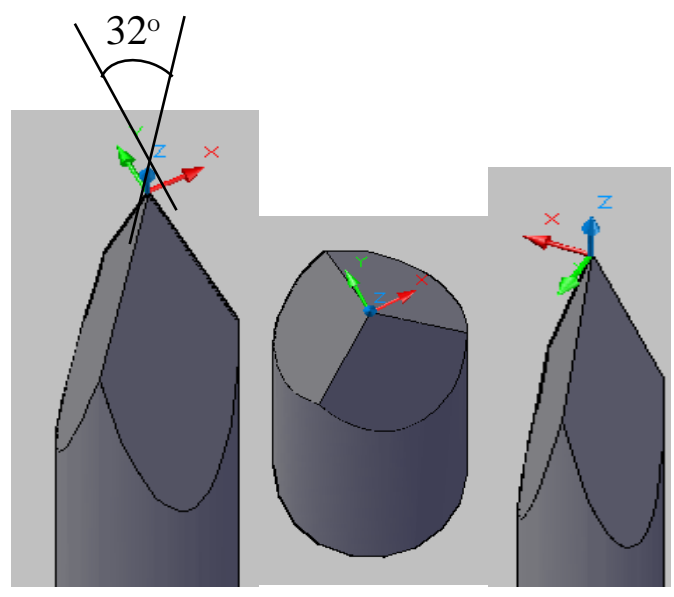

Figure 8. Three-cutter-edged pantograph knife
Moreover in the present study, the results have been shown in table 1 . by doing various relief studies on cutter tool conic angles of between $30^{\circ}$ and $38^{\circ}$. Here, the abrasion and breakage of cutter tool is in negative direction while relief formation shows positive development as long as conic angles decrease. The more conic angles the less relief acceptability and the more tool life (Table 1).

$>$ Relief acceptability (a): Formation of adequate pressure mark by the mold on the leather belt.

$>$ Abrasion of cutter edge on cutter tool (b): Not making trimming during cutting process of the tool shown in Figure 9.

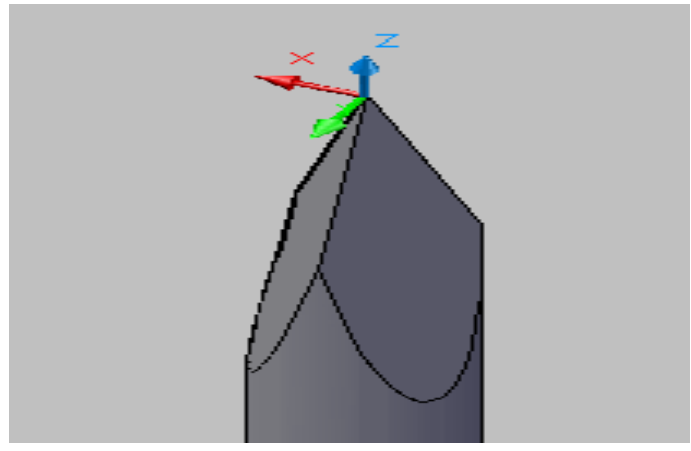

Figure 9. Cutter tool, diamond carbide (56 HRC) pantograph knife

Table 1. Conic angles of three-cutter-edged pantograph knife

\begin{tabular}{|c|c|c|c|c|c|}
\hline $\begin{array}{l}\text { The taper angle } \\
\text { Thickness of Relief }\end{array}$ & $30^{\circ}$ & $32^{\circ}$ & $34^{\circ}$ & $36^{\circ}$ & $38^{\circ}$ \\
\hline $1,5 \mathrm{~mm}$ & $\mathrm{c}, \mathrm{a}$ & $\mathrm{a}$ & $\mathrm{a}$ & $\mathrm{a}$ & $\mathrm{a}, \mathrm{e}, \mathrm{d}$ \\
\hline $2 \mathrm{~mm}$ & $\mathrm{c}, \mathrm{a}$ & $\mathrm{a}$ & $\mathrm{a}$ & $\mathrm{a}$ & $\mathrm{e}, \mathrm{d}$ \\
\hline $2,5 \mathrm{~mm}$ & $\mathrm{~b}, \mathrm{c}, \mathrm{a}$ & $\mathrm{c}, \mathrm{a}$ & a & $e, d$ & $e, d$ \\
\hline $3 \mathrm{~mm}$ & $\mathrm{~b}, \mathrm{c}, \mathrm{a}$ & $\mathrm{b}, \mathrm{c}, \mathrm{a}$ & $\mathrm{c}, \mathrm{a}, \mathrm{d}$ & $e, d$ & e, $d$ \\
\hline $3,5 \mathrm{~mm}$ & $b, c$ & $\mathrm{a}, \mathrm{b}, \mathrm{c}, \mathrm{d}, \mathrm{e}$ & $e, c, d$ & $e, d$ & e, $d$ \\
\hline Assessment & $\begin{array}{c}\text { Relief } \\
\text { acceptability }\end{array}$ & $\begin{array}{c}\text { Abrasion of } \\
\text { cutter edge on } \\
\text { cutter tool }\end{array}$ & $\begin{array}{l}\text { Breakage of } \\
\text { cutter tool } \\
\text { conic tip }\end{array}$ & Tool life & $\begin{array}{l}\text { Relief loss of } \\
\text { form }\end{array}$ \\
\hline Symbol & $\mathrm{a}$ & $\mathrm{b}$ & $\mathrm{c}$ & d & e \\
\hline
\end{tabular}


$>$ Breakage of cutter tool conic tip (c): Shortening and shape loss of cutting size of the tool shown in Figure6.

$>$ Tool life (d): The ability of cutter tool to be able to process the whole material.

$>$ Loss of relief shape (e): The discord in tool conic angle during the selection of tool parameters and the errors made during the formation of cutter tool relief.

- The diamond carbide (56 HRC) knife which is the cutter tool in $6 \mathrm{~mm}$ diameters is tied to the holder clamp.

- The raw bar is tied to the CNC pantograph machine in the position of $X=40 \mathrm{~mm}, Y=1350$ $\mathrm{mm}$ and $\mathrm{Z}=20 \mathrm{~mm}$ as its stock material sizes are so determined.

- While creating tool paths, it is possible to scan the material length between 0 and $1350 \mathrm{~mm}$ along $\mathrm{Y}$ axis or material width between 0 and $40 \mathrm{~mm}$ along $\mathrm{X}$ axis. For instance, cutter tool can complement the $1350 \mathrm{~mm}$ by proceeding $0,07 \mathrm{~mm}$ step on $\mathrm{Y}$ axis with the movement of turning between 0 and $40 \mathrm{~mm}$ or cutter tool can complement the $40 \mathrm{~mm}$ by proceeding $0,07 \mathrm{~mm}$ step on $\mathrm{X}$ axis with the movement of turning between 0 and 1350. However, the tool path designed in artistic CAM program has been chosen as trimming along $\mathrm{Y}$ axis by proceeding 0,07 $\mathrm{mm}$ step on $\mathrm{Y}$ axis. Thus, it has been aimed to prevent tool breakage and abrasion of tool cutter edge (Figure 10).

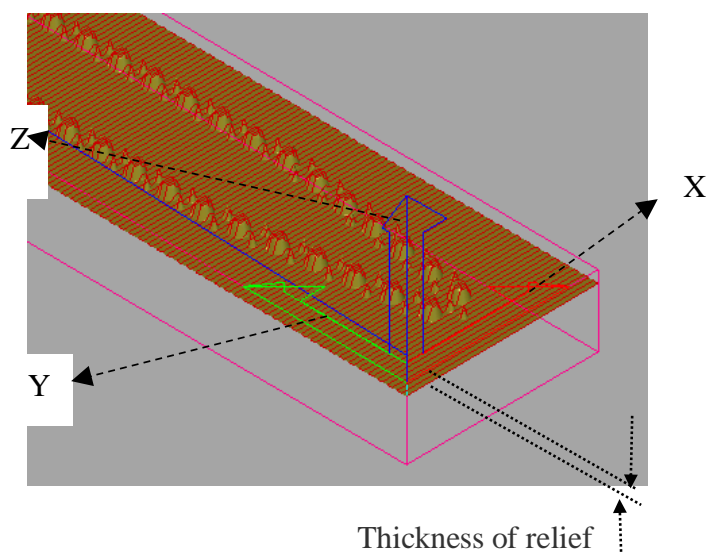

Figure 10. Trimming direction (along $\mathrm{Y}$ axis)

\subsection{Parameters of Cutter Tool}

In artistic tool path program (Art CAM), tool parameters have been selected as in Figure 11. Here, it has been determined that cutter tool is diamond carbide (56 HRC) pantograph knife, diameter of cutter tool is $6 \mathrm{~mm}$, tool tip angle is $32^{\circ}$, height of trimming is $5 \mathrm{~mm}$, length of cutter edge is $10,46 \mathrm{~mm}$, tool proceeding step is $0,07 \mathrm{~mm}$ (along $\mathrm{Y}$ axis), engine speed is 20000 speed/minute, cutting speed along $X$ axis is 1800 $\mathrm{mm} /$ minute, cutting speed along $Z$ axis is 500 $\mathrm{mm} /$ minute. These values are experimental results used in many relief pattern mold productions[1-3].

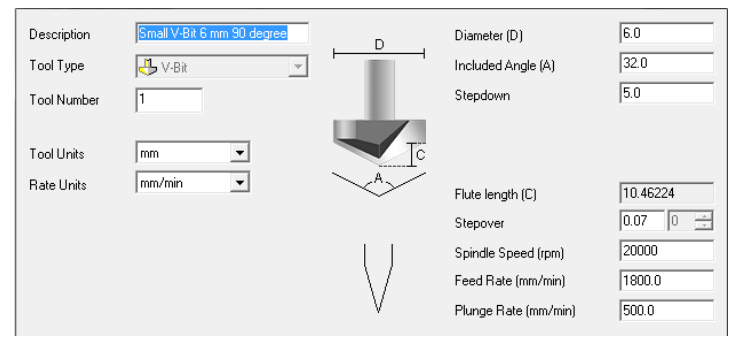

Figure 11. Parameters of cutter tool

Trimming processes of various relieves cutter tool proceeding steps of which are between $0,06 \mathrm{~mm}$ and $0,1 \mathrm{~mm}$ have been investigated. These investigations have shown that the bigger the proceeding step the smaller the mold production time and also the smaller the relief acceptability; the smaller the proceeding step the bigger the mold production time and also the bigger achievement of relief obtaining. Values obtained by various relief thicknesses are shown in Table 2.

\section{CONCLUSION}

Computer aided tool path is produced in order to produce hot pressure belt pattern molds made of brass material. Investigating the artistic CAM program for this purpose, it has been determined as the most appropriate in terms of tool life that diamond carbide tools are sharpened as threecutter-edged and tool tip angle is $32^{\circ}$ and tool proceeding step is $0,07 \mathrm{~mm}$ preferring lower 
Table 2. Cutter tool proceeding step

\begin{tabular}{|c|c|c|c|c|c|}
\hline Amount of progress (Step) & $0,06 \mathrm{~mm}$ & $0,07 \mathrm{~mm}$ & $0,08 \mathrm{~mm}$ & $0,09 \mathrm{~mm}$ & $0,1 \mathrm{~mm}$ \\
\hline $1,5 \mathrm{~mm}$ & $a, d, t$ & $a, d, t$ & $a, d, t$ & $c, d$ & $b, c$ \\
\hline $2 \mathrm{~mm}$ & $a, d, t$ & $a, d, t$ & $a, d, t$ & $b, c, d$ & $b, c$ \\
\hline $2,5 \mathrm{~mm}$ & $a, d, t$ & $a, d, t$ & $a, b, c, d, t$ & $b, c$ & $b, c$ \\
\hline $3 \mathrm{~mm}$ & $a, c, d, t$ & $a, b c, d, t$ & $a, b c, t$ & $b, c$ & $b, c$ \\
\hline $3,5 \mathrm{~mm}$ & $b, c, t$ & $c, b, t$ & $c, b, t$ & $b, c$ & $b, c$ \\
\hline Assessment & $\begin{array}{c}\text { Relief } \\
\text { acceptability }\end{array}$ & $\begin{array}{c}\text { Abrasion of } \\
\text { cutter edge on } \\
\text { cutter tool }\end{array}$ & $\begin{array}{l}\text { Breakage of } \\
\text { cutter tool } \\
\text { conic tip }\end{array}$ & $\begin{array}{l}\text { Length of } \\
\text { tool life }\end{array}$ & $\begin{array}{c}\text { An increase in mold } \\
\text { production time }\end{array}$ \\
\hline Symbol & $a$ & $b$ & $c$ & $d$ & $t$ \\
\hline
\end{tabular}

proceeding step results in increasing mold production time and higher one results in breakage of tool cutter edge. Preferring lower sharpening angle for tool tip results in breakage of tool tip and preferring higher one results in edge losses on relief height. Moreover, processing with trimming $0,07 \mathrm{~mm}$ step along $\mathrm{Y}$ axis causes to lengthen the tool life and processing with trimming $0,07 \mathrm{~mm}$ step along $\mathrm{X}$ axis causes to breakage of cutter tool tip. Investigating the problems happening during mold production such as relief acceptability, abrasion of cutting edge on cutter tools, breakage of cutter tool tip, tool life and loss of relief shape, evaluation results in Table 1 and Table 2 have been obtained.

\section{REFERENCES}

1. Wep Sites of Different Producers of Digisiting equipments: www.artcam.com, <autodesk.com>, <metris.com>.

2. Mendi F., 2006. Takım Tezgahları Teori ve Hesapları, ISBN:975-6009-53-5, Ankara.

3. Tabellenbuch Metal, Verlag EuropaLehrmittel, Nourney, Vollmer GmbH \&Co.

4. Akkurt M., 1993. Talaş kaldırma ve takım tezgahlar1 problemleri, ISBN:975-511-083-6, İstanbul.

5. Mendi F., Kişioğlu Y., Taşkesen A., 2012. Solidworks Çizim-Modelleme-Analiz, ISBN:978-605-4562-45-9, Ankara.
6. Mendi F., Toktaş I., Eldem C., Taşkesen A., 2008. Autocad ile Çizim ve Modelleme, ISBN:978-9944-165-97-6, Ankara.

7. Bagci E., 2009. Advances in Engineering Software 40 407-418,

8. Budak I., 2004. Development of a System for Reverse Engineering Based Design of Complex Shapes with Emphasis on Data-Point Pre-Processing. in: Proceedings of 11th International CIRP Life Cycle Engineering Seminar Product Life Cycle-Quality Management Issues Belgrade,. p. 223-229. 